\title{
Association between Depression and Social Demographic Factors in a Nigerian Family Practice Setting
}

\author{
R. O. Shittu ${ }^{1 *}$, L. O. Odeigah ${ }^{2}$, B. A. Issa ${ }^{3}$, G. T. Olanrewaju ${ }^{3}$, \\ A. O. Mahmoud ${ }^{4}$, M. A. Sanni ${ }^{5}$ \\ ${ }^{1}$ Department of Family Medicine, Kwara State Specialist Hospital, Sobi, Ilorin, Nigeria \\ ${ }^{2}$ Department of Family Medicine, University of Ilorin Teaching Hospital, Ilorin, Nigeria \\ ${ }^{3}$ Department of Behavioural Sciences, University of Ilorin Teaching Hospital, Ilorin, Nigerias \\ ${ }^{4}$ Department of Ophthalmology, University of Ilorin Teaching Hospital, Ilorin, sNigeria \\ ${ }^{5}$ Department of Haematology, Kwara State Specialist Hospital, Sobi, Ilorin, Nigeria \\ Email: ${ }^{*}$ oorelopehospital@gmail.com, lodeigah@yahoo.com, issababa2002@yahoo.com, \\ laromoye554@yahoo.com, mahmoud_ao@yahoo.com, maskareem2009@yahoo.com
}

Received December $7^{\text {th }}$, 2013; revised January $11^{\text {th }}, 2014$; accepted January $20^{\text {th }}, 2014$

Copyright (c) 2014 R. O. Shittu et al. This is an open access article distributed under the Creative Commons Attribution License, which permits unrestricted use, distribution, and reproduction in any medium, provided the original work is properly cited. In accordance of the Creative Commons Attribution License all Copyrights $\mathbb{C}$ 2014 are reserved for SCIRP and the owner of the intellectual property R. O. Shittu et al. All Copyright (C) 2014 are guarded by law and by SCIRP as a guardian.

Objectives: Although depression is one of the more common illnesses in outpatients' clinic, it is often overlooked. Besides accurate identification and treatment is challenging. As pertinent as demographic factors are in explaining the variability of depressive symptoms, there is paucity of data in Nigeria in particular, and West Africa in general, hence the need to bring into lime light the association between depression symptoms and socio-demographic factors in a General Outpatients Clinic in Nigeria, West Africa. Methods: Following institutional ethics committee approval, four hundred newly registered patients who attended the General Out Patients Department (GOPD) of Kwara State Specialist Hospital, Ilorin, Nigeria, were selected by systematic random sampling and studied. The Patients Health Questionnaire-9 (PHQ-9) specifically developed for use in primary care with acceptable reliability, validity, sensitively was used. Association between each socio-demographic factor and depression was sought. Results: One hundred and seventy eight (44.5\%) out of the four hundred respondents were found to have one form of depression or the other. There was minimal depression in 119 (29.8\%), mild in 54 (13.4\%), moderate in 2 $(0.5 \%)$, and severe in $3(0.8 \%)$. There was strong statistical association between depression and age group, sex, marital status, level of education, occupation and monthly income, p-values $0.008,0.000,0.000$, $0.003,0.000,0.001$ respectively. However, religion $(p=0.541)$ and ethnicity $(p=0.567)$ were of no statistical importance. Conclusion: The prevalence of depressive symptoms among patients attending family practice clinics was high. There was also strong association between depression and socio-demographic factor. Family physician should have high index of suspicion to patients with vague somatic complaints and the aforementioned socio-demographic factors. Early detection of depression can be enhanced by screening patients for this disorder, when they attend the hospital for other reasons.

Keywords: Depression; Social Demographic Factors; Nigerian; Family Practice Setting

\section{Introduction}

Depression is among the leading causes of disability in adults. It affects individuals, families, business, and society (USPSTF 2010). The Task Force of Community Preventive Services recommended clinic-based depressive care management to reduce depression in older adults on the basis of sufficient evidence and home base depressive care management (USPSTF 2010). In 2002, the US Preventive Services Task Force (USPSTF) found at least fair evidence to recommend that adults should be screened for depression in clinical practices that have system in place to ensure accurate diagnosis, effective treatment and follow up (Corson, Gerrity, \& Dobscha, 2004).

\footnotetext{
*Corresponding author.
}

Depressive symptoms in family practice clinics are often undetected, despite the fact that they constituted a major presentation in general outpatients clinics (Morakinyo, 2002; Ohaeri \& Jegede, 1991; Jegede, 1999; Krupinski \& Tiller, 2001). The prevalence rates of depression range between $11.7 \%$ and $34.4 \%$ in Nigeria (Morakinyo, 2002). Ohaeri \& co-workers (1991) reported $49 \%$ at University College Hospital, Ibadan, Nigeria. The prevalence rates of depression are higher in Nigerians because of bio-psycho-social factors (Morakinyo, 2002), which included abject poverty, poor socio-economic factor, lack of social cohesion, numerous stressful life events and high rates of infectious diseases.

Based on previous studies, risk factors for depressive illness in the elderly can be grouped into psychosocial, biological, personality characteristics, medication and socio-demographic fac- 
tors. Psychosocial factors include stressful life events e.g. bereavement, financial failures, loneliness etc. (Bruce, 2001). Biological factors include: female gender, folate and vitamin B12 deficiency, "vascular depression" where stroke is implicated and chronic or severe physical pain. Personality traits include: low self esteem, extreme dependency and pessimism. Medication include: anxiolytics, tranquilizers, anti inflammatory, antiinfective agents, beta and calcium channel blockers, hormonal agents, cardio tonic drugs and alcohol. Finally, low socio-economic status, poor educational background and widowhood are socio-demographic factors associated with depression (Mills \& Henretta, 2001).

Depression tends to be marked in Africans by somatic symptoms, which may explain why it is under-diagnosed or underrecognized (Ohaeri \& Jegede, 1991). Early detection of depression can be enhanced by screening person for the disorder when they attend a hospital for other reasons (Edward, 2000). The family practice clinic provides an excellent opportunity for this, as most patients present first at the clinic for all types of illnesses. Despite the high prevalence of depression, there is a paucity of data among patients seen in family practice clinics in NorthCentral Nigeria in particular and West African in general. Therefore, this study was undertaken to provide data on the effects of socio-demographic factors on depression among patients attending the General Out-Patients Department (GOPD) of Kwara State Specialist Hospital Nigeria.

\section{Methodology}

This study was conducted at the General Outpatients Clinic of Kwara State Specialist Hospital, Ilorin, North Central Nigeria. The target populations were the newly registered patients attending the clinic, which serve as a referral Hospital for Oyo, Osun and Kogi State of Nigeria.

The sample size was estimated using the Fisher's Formular

(Araoye, 2003), $\mathrm{n}=\frac{\mathrm{Z}^{2} \mathrm{p}(1-\mathrm{p})}{\mathrm{e}^{2}}$

$$
\text { Therefore: } \mathrm{n}=\frac{(1.96)^{2} 0.59(1-0.59)}{(0.05)^{2}}=371.7
$$

Using 59.6\% from a previous study (Afolabi \& co-workers, 2008), as the best estimate of depressive disorders among patients in a Nigeria Family practice population, a minimum sample size of 371 was calculated, but 400 was used to increase the reliability of the study.

A systematic random sampling method was used in recruiting respondents for this study. Thirty new patients were registered daily, making a total of 210 patients per week and 840 for the period of study from October 30 to November 30, 2013. Using a systematic random sampling method, a sampling interval of 4 was obtained $(840 / 210=4)$. Already identified depressed subjects who were on treatment and those who refused to give consent were excluded from the study. Pretesting was carried out at the Kwara State Civil Service Hospital, using 40 respondents ( $10 \%$ of the sample size). Ethical approval was obtained from the Ethical Review Committee of the Kwara State Ministry of Health before commencement of the study. The respondents were adequately informed about the nature of the study and its benefits. An interviewer administered questionnaire was used.

The Patients Health Questionnaire (PHQ-9) (Krooenke, Spit- zer, \& Williams, 2003) is a brief, 9-item, patients self-report depression assessment tool that was derived from the interviewbased PRIME-MD (Spitzer and colleagues, 1994). It was specifically developed for use, in primary care general medical settings. Many depression screening and severity tools have been used in primary care, with good results. The PHQ-9, however, offers several advantages to other tools. Because the items and the scoring of items on the PHQ-9 are identical to the symptoms and signs of DSM-4 major depression, the tool is easily understood with very high face validity for patients and clinicians in primary care. Many other instruments use a 1-week time frame, but the PHQ-9 uses a 2-week time frame, which conforms to DSM-4 criteria. It is the only tool that was specifically developed for use as a patient self-administered depression diagnostic tool, rather than as a severity or screening tool. It is the only short self-report tool that can reasonably be used both for diagnosis of DSM-4 major depression as well as for tracking of severity of major depression over time (Kroenke, Spitzer, \& Williams 2001). Psychometric evaluation of the PHQ-9 revealed a sensitivity ranging from $62 \%$ - 92\% and a specificity between 74\% - 88\% (Kroenke, 2003; Spitzer, 1994). All subjects screened positively for depression using Patients Health Questionnaire-2 (PHQ-2), which was the first two questions of PHQ-9, triggered full diagnostic interviews by the behavioural scientists.

The PHQ-9 was administered to all the respondents, to screen for depression, until the estimated sample size of 400 was obtained. Respondents who scored one and more were assessed clinically for depression. Scoring and level of depression was assessed viz: (1-4). Minimal depression, (5-9) Mild depression, (10-14) Moderate depression, (15-19). Moderately severe depression, and (20-27). Severe depression. Some direct depression care, such as care support, coordination, case management, and treatment was embarked on.

Completed questionnaire and measurements were entered into a computer data base. The data were analyzed using the epidemiological information (Epi-info) 2005 software package of Center for Disease Control and Prevention (CDC). The 2 by 2 contingency tables were used to carry out Chi-square test and to find out the level of significance and values less than 0.05 were regarded as statistically significant.

\section{Results}

Table 1, displays the socio-demographic characteristics of the respondents. Females 139 (78.0\%) out numbered male 39 (22.0\%). Depression was more prominent in the age group 5160 years more married than single. Depression was also common among respondents' without formal education. Those with low income or no income constituted the majority of depressed patients.

Figure 1, depicted that 178 (44.5) were depressed. 119 (29.8\%) had minimal depression, 54 (13.5\%) mild, 2 (0.5\%) moderate while $3(0.8 \%)$ were severely depressed.

Table 2, shows that there was strong statistical association between age, sex, marital status, level of education, occupation, and monthly income, (p-values 0.008, 0.000, 0.000, 0.003, 0.000 and 0.001 respectively) while religion (p-value 0.541 ) and ethnicity (p-value 0.567 ) were not significant.

Table 3, shows the clinical evaluation of the patient health questionnaire-9 (PHQs-9) of the respondents. Fifty respondents 
Table 1.

Socio-demographic characteristics of the respondents.

\begin{tabular}{|c|c|}
\hline Age Group & \\
\hline $21-30$ & $24(13.5)$ \\
\hline $31-40$ & 23(12.9) \\
\hline $41-50$ & $47(26.4)$ \\
\hline $51-60$ & $51(26.7)$ \\
\hline$>61$ & 33(18.5) \\
\hline \multicolumn{2}{|l|}{ Sex } \\
\hline Male & $39(22.0)$ \\
\hline Female & 139(78.0) \\
\hline \multicolumn{2}{|l|}{ Marital status } \\
\hline Married & 102(57.3) \\
\hline Single & $12(6.7)$ \\
\hline Divorced & $6(3.3)$ \\
\hline Separated & $12(6.7)$ \\
\hline \multicolumn{2}{|l|}{ Religion } \\
\hline Christianity & $27(15.2)$ \\
\hline Islam & 151(84.8) \\
\hline \multicolumn{2}{|l|}{ Education } \\
\hline Non-formal & 108(60.7) \\
\hline Primary & $22(12.4)$ \\
\hline Secondary & $25(14.0)$ \\
\hline Tertiary & 23(12.9) \\
\hline \multicolumn{2}{|l|}{ Occupation } \\
\hline Trader & $56(31.5)$ \\
\hline Civil servant & $27(15.2)$ \\
\hline Self employed & $73(41.0)$ \\
\hline Unemployed & $19(10.7)$ \\
\hline Student & $3(1.6)$ \\
\hline \multicolumn{2}{|c|}{ Monthly Income (N) } \\
\hline No Income & $28(15.7)$ \\
\hline$\leq 20000$ & $129(72.5)$ \\
\hline $20001-30000$ & $10(5.6)$ \\
\hline $30001-40000$ & $6(3.4)$ \\
\hline $40001-50000$ & $3(1.7)$ \\
\hline$>50000$ & $2(1.1)$ \\
\hline
\end{tabular}

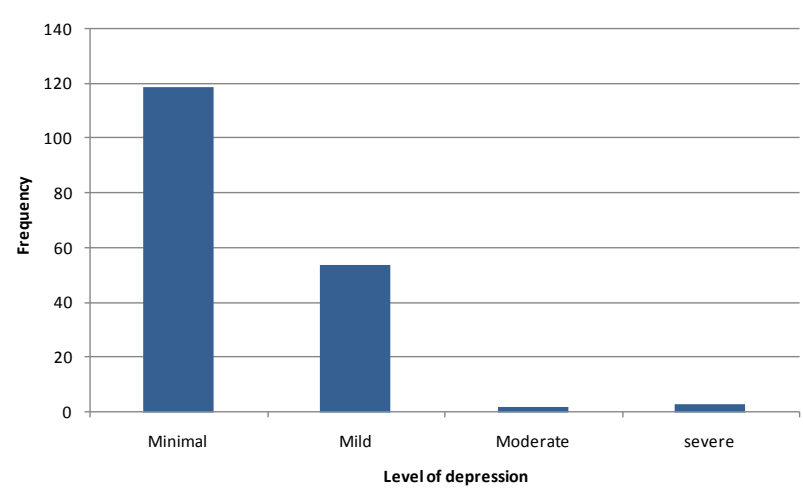

Figure 1.

Spectrum of depression of the respondents. attested to feeling down, depressed, or hopeless on several days while 58, had little interest or pleasure in doing things. Seventy eight had trouble falling or staying asleep, or sleeping too much. Though none thoughts of hurting self, 43 feel bad or failure to self and to the family.

\section{Discussion}

In this study one hundred and seventy-eight subjects (44.5\%) were found to have one form of depression or the other. There was minimal depression in 119 (29.8\%), mild in 54 (13.5\%), moderate in $2(0.5 \%)$ and severe depression in $3(0.8 \%)$. This prevalence was comparable to the $49 \%$ reported by Ohaeri \& Jegede at Ibadan, South Western Nigeria in 1991, and also to the $40 \%$ reported by Patel (1998) in Zimbabwe, but lower than Dolittle \& Farrell (2001) who reported a prevalence rate of $62 \%$ in the United States.

Differences between the observed prevalence in this study and the values cited from the more recent US and Zimbabwe studies may reflect a variation in local rates of predisposing factors for depression in the various communities, as had also been suggested by (Judd et al., 2002). Probable reasons for these differences included the effects of a severely depressed national economy on the psychological state of the subjects. There had been a general decline in per capital income from $\$ 1000$ in 1988, the period when Ohaeri \& Jegede (1991), conducted their studies, to $\$ 260$ in 1998 . Nigeria is classified as a low-middle income country with a Gini Index of 43.7 and income per capital of $\$ 1490$ (Okechukwu et al., 2012). There are also widespread and increasing levels of poverty in Nigeria. This is in consonant with the WHO, who cited poverty as a recognized factor in the increasing prevalence of depression worldwide (WHO, 2006; WDR, 2001).

In this study, a significant association existed between depression and low income $(\mathrm{p}=0.001)$. This was comparable to other studies (Patel, 1999; Kahn, 2000; Araya, 2003). This was similar to the findings in the province of Ontario, in Canadian Health Survey, where the highest prevalence of depression (18.4\%), was seen in household, with an income level of less than $\$ 10,000$ per year (Offord et al., 1996). Income is the most significant social determinants of health, because it determines one's overall living conditions, affect one's psychological condition, and help shape one's diet and eating habits. Low-income people living in poverty cannot afford healthy food, sufficient clothing and good housing all of which are necessary preconditions of good health.

Depression was found to be commoner among the subjects with no formal education. Seventy-one of those without formal education had minimal depression while 37 presented with mild level of depression. On the other hand, 16 of those with tertiary level of education had minimal, 4 had mild while 2 had moderate level of depression. This was statically important ( $\mathrm{p}=$ 0.003). This findings was in concord with other studies, in which low level of education was strongly linked with depression (Okulate, 1999; Barkow, 2003; Shiels, 2004). Education is a critical social determinants of health because, people with higher levels of education are often healthier than people with lower levels of educational attainment.

Moreover, the findings of this study revealed that depression was more common in the age group 51 - 60 years, with strong association between age and depression $(p=0.008)$. This was in agreement with other studies (Sinha, 1997; Gomez et al., 
Table 2.

Association between socio-demographic variables and depression.

\begin{tabular}{|c|c|c|c|c|c|c|}
\hline & \multicolumn{4}{|c|}{ DEPRESSION } & \multirow{2}{*}{ Total } & \multirow[b]{2}{*}{ Chi-square } \\
\hline & Minimal Depression & Mild Depression & Moderate Depression & Severe Depression & & \\
\hline \multicolumn{7}{|l|}{ Age } \\
\hline $21-30$ & 15 & 6 & 2 & 1 & 24 & \multirow[t]{6}{*}{0.008} \\
\hline $31-40$ & 13 & 8 & 0 & 2 & 23 & \\
\hline $41-50$ & 36 & 11 & 0 & 0 & 47 & \\
\hline $51-60$ & 31 & 20 & 0 & 0 & 51 & \\
\hline$>=61$ & 24 & 9 & 0 & 0 & 33 & \\
\hline Total & 119 & 54 & 2 & 3 & 178 & \\
\hline \multicolumn{7}{|l|}{ SEX } \\
\hline Male & 33 & 3 & 0 & 3 & 39 & \multirow[t]{3}{*}{0.000} \\
\hline Female & 86 & 51 & 2 & 0 & 139 & \\
\hline Total & 119 & 54 & 2 & 3 & 178 & \\
\hline \multicolumn{7}{|l|}{ ETHNICITY } \\
\hline Hausa & 116 & 51 & 2 & 3 & 172 & \multirow[t]{5}{*}{0.567} \\
\hline Yoruba & 3 & 1 & 0 & 0 & 4 & \\
\hline Igbo & 0 & 2 & 0 & 0 & 2 & \\
\hline Others & 0 & 2 & 0 & 0 & 2 & \\
\hline Total & 119 & 54 & 2 & 3 & 178 & \\
\hline \multicolumn{7}{|l|}{ RELIGION } \\
\hline Christianity & 21 & 6 & 0 & 0 & 27 & \multirow[t]{3}{*}{0.541} \\
\hline Islam & 98 & 48 & 2 & 3 & 151 & \\
\hline Total & 119 & 54 & 2 & 3 & 178 & \\
\hline \multicolumn{7}{|c|}{ MARITAL STATUS } \\
\hline Married & 73 & 27 & 2 & 0 & 102 & \multirow[t]{6}{*}{0.000} \\
\hline Single & 7 & 2 & 0 & 3 & 12 & \\
\hline Divorced & 5 & 1 & 0 & 0 & 6 & \\
\hline Separated & 6 & 6 & 0 & 0 & 12 & \\
\hline Widow & 28 & 18 & 0 & 0 & 46 & \\
\hline Total & 119 & 54 & 2 & 3 & 178 & \\
\hline \multicolumn{7}{|c|}{ LEVEL OF EDUCATION } \\
\hline Non - formal & 71 & 37 & 0 & 0 & 108 & \multirow[t]{5}{*}{0.003} \\
\hline Primary & 16 & 6 & 0 & 0 & 22 & \\
\hline Secondary & 16 & 7 & 0 & 2 & 25 & \\
\hline Tertiary & 16 & 4 & 2 & 1 & 23 & \\
\hline Total & 119 & 54 & 2 & 3 & 178 & \\
\hline \multicolumn{7}{|c|}{ OCCUPATION } \\
\hline Trader & 38 & 18 & 0 & 0 & 56 & \multirow[t]{6}{*}{0.000} \\
\hline Civil servant & 19 & 4 & 2 & 2 & 27 & \\
\hline Self employed & 45 & 28 & 0 & 0 & 73 & \\
\hline Unemployed & 15 & 4 & 0 & 0 & 19 & \\
\hline Student & 2 & 0 & 0 & 1 & 3 & \\
\hline Total & 119 & 54 & 2 & 3 & 178 & \\
\hline \multicolumn{7}{|c|}{ Monthly Income (N) } \\
\hline No Income & 24 & 2 & 1 & 1 & 28 & \multirow{7}{*}{0.001} \\
\hline$\leq 20000$ & 79 & 50 & 0 & 0 & 129 & \\
\hline $20001-30000$ & 8 & 1 & 0 & 1 & 10 & \\
\hline $30001-40000$ & 5 & 1 & 0 & 0 & 6 & \\
\hline $40001-50000$ & 2 & 0 & 1 & 0 & 2 & \\
\hline$>50000$ & 1 & 0 & 0 & 1 & 3 & \\
\hline Total & 119 & 54 & 2 & 3 & 178 & \\
\hline
\end{tabular}




\section{R. O. SHITTU ET AL.}

Table 3.

The patient health questionnaire -9 (PHQ-9) ${ }^{12-14}$.

\begin{tabular}{|c|c|c|c|c|c|c|}
\hline \multicolumn{2}{|r|}{$\begin{array}{l}\text { Over the last } 2 \text { weeks, how often have you been bothered } \\
\text { by any of the following problems? }\end{array}$} & \multirow{2}{*}{$\begin{array}{c}\text { Not at all } \\
338\end{array}$} & \multirow{2}{*}{$\begin{array}{c}\text { Several days } \\
58\end{array}$} & \multirow{2}{*}{$\begin{array}{c}\text { More than half the days } \\
4\end{array}$} & \multirow{2}{*}{$\begin{array}{c}\text { Nearly every day } \\
0\end{array}$} & \multirow{2}{*}{$\begin{array}{r}\text { Total } \\
400\end{array}$} \\
\hline 1. & Little interest or pleasure in doing things & & & & & \\
\hline 3. & Trouble falling or staying asleep, or sleeping too much & 288 & 78 & 27 & 7 & 400 \\
\hline 4. & Feeling tired or having little energy & 279 & 85 & 33 & 3 & 400 \\
\hline 6. & $\begin{array}{l}\text { Feeling bad about yourself-or that you are a failure or } \\
\text { have let yourself or your family down }\end{array}$ & 351 & 43 & 3 & 3 & 400 \\
\hline 7. & $\begin{array}{l}\text { Trouble concentrating on things, such as reading the } \\
\text { newspaper or watching television }\end{array}$ & 367 & 30 & 3 & 0 & 400 \\
\hline 8. & $\begin{array}{l}\text { Moving or speaking so slowly that other people could have } \\
\text { noticed, or the opposite-being so fidgety or restless that } \\
\text { you have been moving around a lot more than usual }\end{array}$ & 392 & 5 & 3 & 0 & 400 \\
\hline 9. & $\begin{array}{l}\text { Thoughts that you would be better off dead, or of hurting } \\
\text { yourself in some way. }\end{array}$ & 397 & 0 & 3 & 0 & 400 \\
\hline
\end{tabular}

2004). Gomez-Restrepo et al. (2004) reported a higher prevalence of depression in person older than 45 years. Similarly, depression symptoms was reported to be twice in the older age group than in younger adults in Butajira, Ethiopia (Kebede et al., 2003). This was contrary to the finding of Noori and co-workers, who reported highest prevalence range in the age group of 20 to 24 years and the lowest rate in the age group of 75 years and above. Plausible reason for this could be biological because of hormonal variation in menopause and andropause. It could also be as a result of stressful life events like bereavement, financial failures and loneliness (Bruce, 2001; Mills, 2001). Contrary to the above, a study in Nigeria (Ihezue \& Kumaraswany, 1986) found out that there was no significant association between depression and age, which was similar to a Harvard Medial School study reported that, depression could occur at any age, and that individual, might experience depression at different times of their lives for different reasons (President and Fellows of Harvard College, 2007), hence, there were no significant differences between age group and depression.

Occupation status was found to have a significant relationship with depression in this study. $(p=0.000)$, with $15(8.4 \%)$ of the unemployed having minimal depression while 4(2.2) had mild depression. This was in support of other studies that found a significant association between employment status and depression (Prause, 2001; Comino, 2000; Roos, 2005). This was similar to another study, where depressive features were more common among the unemployed. Depression resulting from unemployment had increased over the years (President and Fellows of Harvard College, 2007), but contrary to the study of Afolabi and colleagues (2008) who found no association between employment and depression. Unemployment leads to poor physical mental health in a number of ways. When patients become unemployed, it is a stressful event that affects their self-esteems. Since employment generates income, a positive identity and the ability to live healthy lifestyles, unemployment leads to impoverishment, psychological stress and participate in health-threatening coping behaviours such as tobacco consumption, alcohol abuse, promiscuity.

Furthermore, in this study, marital status had a negative significant association with depression $(p=0.000)$. This was in support of the findings of Brown et al. who established that marital status had no bearing on the experience of depression (Brown \& co-workers, 2000), but contrary to the findings of Afolabi and colleagues (2008) at Obafemi Awolowo Teaching Hospital Complex (OAUTHC), in Ile-Ife, Nigeria, West Africa; were marriage was indeed extremely beneficial.

There was significant association between depression and gender in this study $(\mathrm{p}=0.008)$. One hundred and thirty-nine females (78\%) had depression, compared to 39 males (22\%). This was contrary to the study of Afolabi and colleagues (2008). Women were more likely to experience depression than men because they carry the double burden of raising children and household work. Gender inequity needs to be regarded as a social determinant of depression. Thus there is a need to pay more attention to gender as determinants of depressive mood.

\section{Conclusion}

The proportion of patients with depressive symptoms in family practice clinics is high and highly correlates with socio-demographic factors and low socio-economic status. Coping mechanism for depression in resource-limited economies, like those of most West African countries, is an important area that needs to be studied further. Increased awareness, information, advocacy and access to healthcare services, especially for the early detection and preventive care of depression, are of critical importance. The family as a focus for health promotion will require the development of practical approaches that employ social variables in the analysis of health and human development strategies, and the recognition of the power of these social variables in the analysis of health and human development strategies, and the recognition of the power of these social variables in influencing mental health.

\section{REFERENCES}

Afolabi, M. O., Abioye-Kuteyi, E. A., Fatoye, F. O., Bello, I. S., \& Adewuya, A. O. (2008). Pattern of depression among patients in a Nigeria family practice population. South African Family Practice, 50, 63-69.

Araoye, M. O. (2003). Data collection in: Research methodology with 
statistics for health and social sciences. Ilorin: Nathadex Publishers, 130-159.

Araya, R., Lewis, G., Rojas, G., \& Fritscho, R. (2003). Education and income: Which is more important for mental health? Journal of Epidemiology \& Community Health, 57, 501-505. http://dx.doi.org/10.1136/jech.57.7.501

Barkow, K., Maier, W., Uatun, T. B., Gansicke, M., Witchen, H. Y., \& Heun, R. (2003). Risk factors for depression at 12-month follow-up in adult primary health care patients with major depression: An international prospective study. Journal of Affective Disorders, 76, 157169. http://dx.doi.org/10.1016/S0165-0327(02)00081-2

Brown, A. C., Brody, G. H., \& Stoneman, Z. (2000). Rural black women and depression: A contextual analysis. Journal of Marriage and Family, 62, 187-198.

Bruce, M. L. (2001). Psychological risk factor for depressive disorder in late life. Biological Psychiatry, 52, 175-184.

Comino, E. J., Harris, E., Silove, D., Maricavasagar, V., \& Harris, M. F. (2000). Prevalence, detection and management of anxiety and depressive symptoms in unemployed patients attending general practitioners. Australian \& New Zealand Journal of Psychiatry, 34, 107113. http://dx.doi.org/10.1046/j.1440-1614.2000.00645.x

Corson, K., Gerrity, M.S., \& Dobscha, S. K. (2004). Screening for depression and Suicidality in a VA primary setting: 2 items are better than 1 item. American Journal of Managed Care, 10, 839-45.

Edward, J. G. (2000). Evidence-based approaches to prevention of depression. Paper presented to medical of Practitioners in Meboume, Sydney and Brishare.

Gomez-Restrepo, C., Bohorquez, A., Pinto, M., et al. (2004). The prevalence of and factors associated with depression in Colombia. Revista Panamericana de Salud Pública, 16, 378-386.

Ihezue, U. H., \& Kumaraswany, N. (1986). Socio-demographic characteristics of depressive illness among Nigerians. Acta Psychiatrica Scandinavica, 73, 128-132. http://dx.doi.org/10.1111/j.1600-0447.1986.tb10577.x

Jegede, R. O. (1999). Depression in Africans revisited: A critical review of literature. African Journal of Medical Science, 8, 125-132.

Judd, F. K., Jackson, H. J., Komiti, A., Murray, G., Hodgins, G., \& Fraser, C. (2002). High Prevalence disorders in urban and rural communities. Australian \& New Zealand Journal of Psychiatry, 36, 104-107. http://dx.doi.org/10.1046/j.1440-1614.2002.00986.x

Kahn, R. S., Wise, P. H., Kennedy, B. P., \& Kawachi, I. (2000). State income inequality, house hold income, and maternal mental and physical health: Cross-sectional national survey. British Medical Journal, 321, 1311-1315. http://dx.doi.org/10.1136/bmj.321.7272.1311

Kebede, D., Alem, A, Deyassa, N., Shibra, T., Legash, A., Beyero, T., et al. (2003). Socio-demography correlates of depressive disorder in Butajgra, rural Ethiopia. Central African Journal of Medicine, 49, 78-83.

Kroenke, K., Spitzer, R. L., \& Williams, J. B. W. (2001). The PHQ-9: Validity of a brief depression severity measure. Journal of General Internal Medicine, 16, 606-613. http://dx.doi.org/10.1046/j.1525-1497.2001.016009606.x

Krooenke, K., Spitzer, R. L., \& Williams, B. (2003). The patient health questionnaire 2: Validity of a two-item depression screener. Medical care, $41,1284-1294$. http://dx.doi.org/10.1097/01.MLR.0000093487.78664.3Cc

Krupinski, J., \& Tiller, J. (2001). Identification and treatment of depression by general practitioners. Australian and New Zealand Journal of Psychiatry, 35, 827-832.

http://dx.doi.org/10.1046/j.1440-1614.2001.00960.x
Mills, T. N., \& Henretta, J. C. (2001). Racial, ethnic and sociodemographic differences in the level of psychosocial difference among older Americans. Research on Ageing, 23, 131-152. http://dx.doi.org/10.1177/0164027501232001

Morakinyo, O. (2002). The nature and diagnosis of depressive disorders in Africans. In O. Morakinyo (Ed.), Handbook for students on mental health posting (pp. 68-69). Ile-Ife: The Department of Mental Health, Obafemi Awolowo University/Obafemi Awolowo University Teaching Hospital Complex.

Offord, D. R., Boyle, M. H., Campbell, D., Goering, P., Lin, E., Wong, M., Racine, Y. A. et al. (1996). One year prevalence of psychiatric disorder in Ortarians 15 to 64 years of age. Canadian Journal of Psychiatry, 41, 559-563.

Ohaeri, J. U., \& Jegede, R. O. (1991). Depression and the general medical practitioner in Nigeria. Medicare, 6, 7-11.

Okechukwu, S. O., Ikechi, O., Innocent, I. C., Joshua, O. A., Basden, J. C., Ayodele, O. F. et al. (2012). Blood pressure, prevalence of hypertension and hypertension related complications in Nigerian Africans: A review World. Journal of Cardiology, 4, 327-340.

Okulate, G. T. (1999). Psychiatric morbidity in private general practice in Lagos, Nigeria. Nigerian Quarterly Journal of Hospital Medicine, 9, 124-126. http://dx.doi.org/10.4314/nqjhm.v9i2.12392

Patel, V., Araya, R., Lima, M. S., Ludermir, A., \& Todd, C. (1999). Women, poverty and common mental disorders in four restructuring societies. Social Science Medicine, 49, 1461-1471. http://dx.doi.org/10.1016/S0277-9536(99)00208-7

Patel, V., Todd, C. H., \& Winston, M. (1998). The outcome of common mental disorders in Harare, Zimbabwe. British Journal of Psychiatry, 172, 53-57. http://dx.doi.org/10.1192/bjp.172.1.53

Prause, J., \& Doole, Y. D. (2001). Favourable employment status change and psychological depression: A two-year follow-up analysis of the National Longitudinal Survey of Youth. Applied Psychology: An International Review, 50, 282-304. http://dx.doi.org/10.1111/1464-0597.00059

President and Fellows of Harvard College (2007). Depression, sex and age. Cambridge, MA: Harvard Health Publications, 1-5.

Roos, E., Lahelma, E., Saastamoinen, P., \& Elstad, J. I. (2005). The association of employment status and family status with health among women and men in four Nordic countries. Scandinavia Journal of Public Health, 33, 250-260. http://dx.doi.org/10.1080/14034940510005680

Shiels, C., Gabbay, M., Cowrick, C., \& Hulbert, C. (2004). Depression in men attending a rural general practice: factors associated with prevalence of depressive symptoms and diagnosis. British Journal of Psychiatry, 185, 239-245. http://dx.doi.org/10.1192/bjp.185.3.239

Sinha, D. (1997). Psychological concomitants of poverty and their implications for education. In Y. Atal (Ed.), Perspectives of educating the poor (pp. 57-118). New Delhi: Abhinav Publications.

Spitzer, R. L., Williams, J. B., Kroenke, K., Linzer, M., deGruy, F. V., Hahn, S. R., et al. (1994). Utility of a new procedure for diagnosing mental disorders in primary care. The PRIME-MD 1000 study. The Journal of the American Medical Association, 272, 1749-1756. http://dx.doi.org/10.1001/jama.1994.03520220043029

US Preventive Services Task Force (2010). Screening for depression in adults: Recommendation statement. American Family Physician, 82, 976-979.

World Bank Development Indicators (2005). Income Per Capita. http://www.finfacts.ie/biz10globaworldincomepercapital.htm

World Development Report 2000/2001 (2001). Attacking poverty. New York: Oxford University Press. 